Anna Walkowiak (University of Warsaw)

\title{
At the source of the lack of the security complex in Northeast Asia
}

\section{Introduction}

Scholars of international relations engaged in regional studies or the theory of world order have created many definitions of a region and regional institutions. Depending on their interest they emphasize the importance of cultural, language, geographical, historical, political or economical cohesiveness to create a region. Though it is widely accepted that regions are the creation of the human mind and so-called natural regions do not exist. Geographical proximity and historical heritage are important in creating bonds between states, but regions are not only geographically determined (S. Kim, 2004, 40-43). In this article the definition created by Joseph Nye will be availed. Here, the term 'region' means a "limited number of states linked by geographical relationship and by a degree of mutual interdependence" (J. Nye, 1968, vii). Institutions are understood here as "persistent and connected sets of rules (formal and informal) that prescribe behavioural roles, constrain activity, and shape expectations" (R. Keohane, 1989, p. 3). Those institutions may occur in different forms, not only traditional international organisations or treaties/agreements, but also informal practices that states treat as binding (M. Timmermann, 2008, p. 2).

The aim of this article is to present the reasons for the lack of security institutions in northeast Asia in the post-Cold War period and assess the Six-Party Talks ability to change this situation in the near future. In this article two theories of international relations will be applied to explain the current state of regional relations. A realistic perspective will be the dominant theoretical approach as it allows us to understand the situation in the region in terms of clash of interests in an anarchic reality. However, a few references to the theory of constructivism's assumptions about the influence of culture are needed to better understand the specifics of the region. 


\section{The Northeast Asia Region and its specifics}

Northeast Asia is a sub-region of East Asia, consisting of the territories of the Democratic People's Republic of Korea (North Korea), the Republic of Korea (South Korea), the People's Republic of China, Japan, and the eastern parts of the Russian Federation, called the Russian Far East. Some authors defining this region also include Mongolia, the Republic of China (Taiwan) and the United States of America (E. Haliżak, 2004, p. 26-32). This paper will concentrate on the six countries that took part in the so-called Six-Party Talks; that is the two Korean states, China, Japan, Russia and the United States. Although the U.S. does not belong to Asia geographically, its interest in the region and geographical proximity, expressed by economic cooperation with other states and military presence, make it a vital participant of regional international affairs. It is not possible to provide a comprehensive view of the regional affairs without taking Washington into consideration, especially while talking about interstate relations in Northeast Asia. The countries involved in the forum, whose aim is to reduce tensions in the Korean Peninsula, are the core of the region. They are the most powerful regional players and in some cases - world players; though Pyongyang can be classified as one of the main global problems. Although their commitment in regional affairs is different, as some of them also belong to other regions or have vital interests elsewhere, without any of them it is not possible to deal with regional problems in a longer perspective (Park, 2005).

Today Northeast Asia is one of the most dynamically developing regions in the world, containing some of the world's largest economies. According to the World Bank's statistics in 2009 the United States, China and Japan respectively had the highest gross domestic product in the world. Also Russia and South Korea were located in the top twenty richest states. This is also the place where the interests of three nuclear great powers clash, which has made Northeast Asia the arena of rivalry between great powers in the past. This situation will probably continue in future. Moreover, Japan and South Korea are able to maintain nuclear weapons without difficulty due to their advance in nuclear technology. Northeast Asia is a region with the heaviest concentration of military in the world (S. Kim, 2004, p. 44). Immanuel Wallerstein described a new world order after the end of the United States hegemony stating that we are witnesses to an "emerging of eight to ten centers of relative geopolitical autonomy. [...] The four strongest such centers are located in what is sometimes called the global North. They are in my opinion the United States (which continues of course to be an extremely strong power center, if far less powerful than previously), Western Europe (based on the critical France-Germany tandem), and Russia. The fourth such center is Northeast Asia, by which the author means China, Korea, and Japan" (Wallerstein, 2010, p. 191). That description shows that Northeast Asia in the meaning of this article sustains 
the most important states in the world and in the future the importance of events that will take place in the region will be even higher than nowadays.

On the other hand, the Northeast Asia region is still plagued by instability divided states, unresolved border issues and, what is most important, the possibility of nuclear proliferation that may lead to a new arms race, undermining the hope for a peaceful growth in the future. The region as a whole is crisis prone, and by crisis it is not only understood as a high dependence on the global economy conditions, but also political and military tensions that often occurred on the Korean Peninsula. Good examples of that proneness are the problems that occurred in the majority of Northeast Asian states during the Asian financial crisis in 1997 and global financial crisis in 2008, as well as the tensions on the Korean Peninsula resulting from provocations by Pyongyang. Common threats and interests in the stabilization of the region should lead to the creation of a model of permanent cooperation between the Northeast Asian states. Proliferation problems are generally viewed as security threats that need a multilateral approach to solve them, because one state, even the most powerful, is not able to stop others from gaining access to weapons of mass destruction (Van Ness, 2008, p. 109-110). If political and security reasons are not enough, we have other causes that are seen as a background to establishing cooperation in the region. Chinese, Japanese and both Korean states' cultures have common Buddhist-Confucian origins that might help build a platform for cooperation. There is also a relationship between the Chinese, Japanese and Russian economies. China can provide manpower, Japan capital and Russia natural resources, which may encourage states to seek ways to cooperate in order to gain market success. However, Northeast Asia is still the least institutionalized region in the world (K. Calder and M. Ye, 2004, p. 191-226; K. Calder and M. Ye, 2010, p. 3-4). This means that even combined security, economic and cultural reasons are not enough to prompt Northeast Asian states to create a regional organization or even less formal institutions. To understand the roots of that phenomenon it is necessary to briefly analyse certain events and trends within the history of interstate relations in the region, with a particular emphasis on the last one hundred and fifty years. The aim of the next part of the paper is not to give a historical background of international relations in the region, but to show the influence of certain events and trends that occurred in the past and are, in my opinion, relevant to the current situation or shaped the image of neighbouring nations.

\section{A brief history of interstate relations in Northeast Asia}

First of all, a long-lasting Chinese hegemony in the region that brought a common Buddhist and Confucian civilization led to the emergence of resistance to China's domination by Korea and Japan. Smaller states feared losing their identity and independence. Although they assimilated part of the achievements of the Chinese 
civilization, they tried to adapt them to their own culture. Due to the disproportion of power between China and other states in the region and the Chinese concept of the world and its place in it, there was no possibility for them to compete with the Chinese Empire during its heyday. The concept of "All-under-Heaven" provided a philosophical explanation for building an empire, in "which co-existed many sub-states independent in their economies, military powers and cultures, but politically and ethically dependent on the empire's institutional centre" (T. Zhao, 2006, p. 34). As it is indicated above Chinese rulers partly accepted the independence of the subordinate states but they did not think in terms of equality. In the Chinese conception the world was ruled as a family and parts of the empire had a strict place in its hierarchy. Under these circumstances there was no place for any structure that implied equality between China and other states; it was a condition for building international institutions. Other states in the region were too weak to create any bond that from China's point of view might have been directed against its rule. Even though the concept evolved into a voluntary tributary system, in which becoming a part of it was a voluntary decision made by the states and participation benefits were greater than the costs of tributary gifts, it was still a hierarchical structure (T. Zhao, 2006, p. 35).

The weakening of China created a power gap, which led to the increasing competition between great powers from outside the region and the rise of Japan in the $19^{\text {th }}$ and the beginning of the $20^{\text {th }}$ century. The residues of that rivalry had and still have a great impact on national identities and are the cause of frequent tensions between Northeast Asian states. Unequal treaties have had a big impact on the Chinese view of international relations and its place in it (Peters, 2012, p. 3). It seems that China was able to deal with the memory of past humiliations, but still there are voices that claim when China reaches strong position, it will threaten the existing word order (Suzuki, 2004, p. 116-119). But this way of thinking generally refers to the future. At present, having their roots in the past, mutual distrust and a frequent reluctance towards other nations in the region are more important in dealing with the heritage of the mentioned period. In the collective memory events such as the brutal conquest of Korea by the Japanese or war crimes Japan committed against Asian nations, such as the Nanking Massacre, are still alive and often determine the view of Tokyo and cause distrust towards its actions. Strong nationalistic movements in all of the Asian countries that are a part of Northeast Asia used the events that occurred before the end of the Second World War to create social support for government or local elite actions. The degree of mutual distrust varies between different nations due to their historical heritage, but the strongest tensions are between China and Japan. Every time a dispute over the Senkaku/ Diaoyu Islands erupted with new power in China, anti-Japanese protests occurred. Interestingly enough, the protesters often stated that the real reason for their participation is the hatred towards Japan caused by Tokyo's former crimes against the Chinese nation (Anti-Japan protests, 2012). Although trade between Japan and 
China increases every year, it does not influence the image of the other state and still clenches in interstate relations causing disturbances in the economic sphere. This is due to the informal boycotts of products or cancellations of planned vacation trips to another country (Baisong, 2012; Watt, 2012). The distrust among the societies of these states that have good relations in Northeast Asia, even strategic ones, is also high. Although since the beginning of the 1990s Russia and China have signed many agreements and often have a common point of view in international affairs, in the Russian Far East, due to the reduction of the Russian population and increasing Chinese migration, the fear of the so-called Chinese threat/ Chinese peril has been re-established with new vigour. Some members of the local authorities increased and used those old fears to achieve personal goals, for example the former governor of Primorsky Krai in his rivalry with Boris Yeltsin. People also opposed the return of the islands on the Amur River to China, which was based on the border treaties using arguments referring to the $19^{\text {th }}$ century. In their opinion China's goal was to change the borders and take over the territories that in the past belonged to the Chinese Empire. It is a popular belief that the People's Republic of China has a nefarious plan to conquer the Russian Far East without using military means to achieve that goal. Beijing is accused of encouraging its citizens to migrate to the North, which will lead to a change in the ethnic structure, and of using its economic predominance to buy Russian land and industry in the Far East (Larin, 2006, p. 60; Lukin, 2003, p. 164-193).

The Second World War strengthens the reluctance between China and Japan and thereby also supports their rivalry for the control over the whole Northeast Asia region. The Cold War added a new surface of division into the conflicted region in the form of a bipolar rivalry of two great powers - the United States and the Union of Soviet Socialist Republics (USSR). Henceforth, Northeast Asia had to deal not only with its local problems, but was involved in a global confrontation. As a result, the situation in the region became dependent on the political relations between the East and the West. Growing tensions between the U.S. and the USSR (along with their allies and satellite states) in the late 1940s and early 1950s resulted in creating and maintaining the division of China and Korea, excluding any form of regional cooperation (Kukułka, 2007, p. 56-61). Inside the Communist ideological camp tensions caused by the differences in doctrines were quickly revealed, but the main cause of problems was the policy of the USSR, which tried to realize its national interests rather than act for the sake of the whole Communist world. For China, being treated as a younger brother for too long without receiving the promised aid was enough. Relations deteriorated from the middle of the 1950s and finally resulted in the Sino - Soviet split in the 1960s (Lüthi, 2008). The conflict between the USSR and China also complicated relations in the region, as there was a new line of instability - a new possible place for the outbreak of war between nuclear powers. Fortunately it climaxed at only a few military incidents on the border, but both states were prepared for a possible 
armed conflict (Robinson, 1972, p. 1175-1202). On the other hand, the split between the communist powers gave China a reason and possibility to seek cooperation with the U.S. in the 1970s, which lead to the creation of a strategic triangle in the region (Kuisong, 2010, p. 21-52).

Unbalanced relations between great powers did not create an atmosphere to seek even informal institutions for coordination or consultation in the region. Smaller states bound by bipolarity were not able to create any institutions on their own. Any idea of integration or even informal cooperation proposed by Japan would be immediately rejected because of the memories of Japanese actions for creating an "Asian Community" and the implementation of the Greater East Asian Co-Prosperity Sphere (Daitōa Kyōeiken), which led to the war and occupation of other states (see more: Duss, 2008, p. 143-154; Haliżak, 2006, p. 30-32). Asian nations, especially South Korea, were generally focused on the post-war reconstruction of their countries; building foundations for economic development rather than using their energy for establishing any forms of permanent cooperatThe post-war situation in Europe and Northeast Asia, a time when weak states needing U.S. help to maintain non-communist governments and clear a division between two blocks that turned both regions in a battle ground between ideologies, allowed for the comparison of political solutions used to ensure peace and security in certain regions. There are voices among scholars that one of the reasons for the lack of creation of a security and cooperation system in Northeast Asia during the Cold War was the U.S. policy. In Europe, the United States provided economic help based on the assumptions of the European Recovery Program, commonly known as the Marshall Plan. One of the conditions for their support was the establishment of a European nations organization whose task would be to manage founds for the economic reconstruction (The "Marshall Plan"). We may argue if it is possible to compare European economies, which before war were the most developed in the world and needed only capital to re-establish prior conditions, with Asian ones that had to be created anew. Still, establishing the Organization for European Economic Co-operation was a milestone in European nations' integration and it provided the necessary experience in cooperation that helped to create European Communities. In Europe, the United States also provided multilateral security guarantees by signing the Washington Treaty, which was the basis for establishing the North Atlantic Treaty Organization. Safe under the U.S. nuclear protection Western Europe could concentrate on building international integration institutions. After the end of the Cold War the organizations existing in Western Europe were gradually extended to post-communist states, including them in permanent regional cooperation that helped reduce tensions. In the case of Northeast Asia, the outbreak of the Korean War ruined the chances of creating the Pacific Pact. The U.S. sought a way to reach an agreement with Japan as soon as possible and was not interested in providing security guarantees for Hong Kong, Singapore and Malaysia. Understandably for Great Britain, a multilateral agreement 
without such guarantees was useless. Consequently, the U.S. chose a different strategy, preferring a bilateral alliance with Japan and South Korea ${ }^{5}$. South Korea and Japan established diplomatic relations in 1965 - twenty years after the end of the Second World War. It is easy to understand why it took so long having in mind the historical legacy between these two states, but it also shows that the so-called San Francisco Treaty System does not create an opportunity for security policy coordination, because different U.S. allies in Asia remained separated from each other (K. Calder and M. Ye, 2010, p. 58-59). At the end of the Cold War there was no organization that could provide a foundation for security cooperation or even consultation on major issues.

\section{Six-Party Talks: Attempt to create multilateral institutions in Northeast Asia}

Tension reduction associated with the end of the Cold War did not lead to establishing a cooperation mechanism in Northeast Asia. However, at the end of the 1980s and at the beginning of the 1990s political leaders presented a few propositions for creating a security framework. These propositions included: Mikhail Gorbachev's idea of expanding regional cooperation using the Council for Security Cooperation in Europe as a model; South Korea's President Roh Taw-woo's idea of a six-party Consultative Conference for Peace in Northeast Asia; or finally the United States Secretary of State James Baker's project of establishing a twoplus-four mechanism for dealing with tensions on the Korean Peninsula. None of those ideas lasted long (Snyder, 2008, p. 1). Peter Katzenstein highlights that the typical preference for Asian states to form informal relations are an obstacle for institutionalization, inspired by governmental initiative and vertical relations between society and states in Asian nations as a restraint for movement from below (Katzenstein, 1997, p. 1-44). Nevertheless, the first nuclear crisis on the Korean Peninsula in 1993 somehow changed the attitudes of states. As stated Jack Snyder: "Ironically, North Korea - as the actor that has catalyzed common concerns that have created a basis for cooperation among the other parties in the region-might be regarded as the biggest promoter of multilateral security cooperation in the region." Although the Four-Party Talks, which included the United States, China, North and South Korea and resulted in the establishment of the Korean Peninsula Energy Development Organization (KEDO), it was not enough to provide stabilization in the long term and the whole KEDO project was not thoroughly prepared. However, it was a great change in the way of thinking, especially in the case of the United States. It gave hope that there is a possibility to have discussions about

5 The San Francisco System contained also United States mutual military agreements with Australia, New Zealand and the Philippines, but those countries are not part of Northeast Asia and as such are not included in the main considerations of this article. 
common security interests instead of ineffective attempts to deal with North Korea in bilateral negotiations. On the other hand, the non-inclusion of Japan and Russia in the talks made them insufficient to achieve established goals. It seems that in the first half of the 1990s Northeast Asian states weren't ready to participate in long-standing negotiations, but the first step was made (Snyder, 2008, p. 2).

The Six-Party Talks established in year 2003, initiated by the People's Republic of China, are nowadays the most probable background for future initialization of Northeast Asia. China's proposition to start multilateral negotiations also shows a new pattern. China is willing to create its image as a responsible power that has forgotten the past and whose main aim is a peaceful rise while at the same time not becoming a threat to the existing world order. Although the Six-Party Talks participants have different interests regarding the main topics of negotiations, still a wish to try to achieve stabilization on the Korean Peninsula through multilateral means is a new quality in regional affairs. On the other hand, the rivalry between the states, especially the great powers, did not vanish. The analysis of the states' attitudes towards the main issues of the Talks shows that they did not give exactly the same priority to all of the topics. For example, for the Russian Federation North Korea's nuclear ambitions are not as important as for Japan. Russia is generally against nuclear weapons proliferation as it leads to the weakening of Moscow's position as one of few nuclear powers, but is not afraid that Pyongyang will use weapons of mass destruction against its territory. For Japan, however, the threat of a nuclear attack from North Korea is higher due to the memory of the Japanese occupation of Korea. All states declared that they are interested in a peaceful reunification of Korea, but in truth none of them is really interested in reaching this goal. Leaving the difficulties in achieving this aim aside, it must be stated that all Six-Party Talks participants are mainly interested in maintaining status quo on the Peninsula. There are different reasons for this policy, but for all of the states the most important is maintaining the existence of North Korea, however without nuclear and missile capabilities (Park, 2005). Other states were ready to support North Korea's regime with humanitarian aid and energy supply for the price of a stabile situation on the Peninsula. In these circumstances North Korea's nuclear tests and attacks against South Korea are attempts to gain a better negotiating position (Otsuka, 2011, p. 66-67).

The Six Party Talks ended in 2010 after the attack on the South Korean ship "Cheonan". The Talks did not achieve their expectations and after a failed launch of a North Korean satellite into orbit in April 2012 Washington and Seoul announced their failure in the containment of Pyongyang's missile program (Snyder and Byun, 2011, p. 79-80; Lee, 2012). However, most participants of the Six-Party Talks have seen the benefits of the negotiations and it is highly possible that after a break the Talks will be established anew. There is now another way of influencing North Korea and all of the states are interested in maintaining its stable existence. The power transition both in North Korea and China focused those states' 
governments' attention on internal matters, but the new leaders may be willing to return to negotiations as a way of securing their influence by succeeding in re-establishing negotiations (Gause, 2012, New Leadership in China). Even assuming that the new leaders will be willing to do so, it is rather impossible to transform the Six-Party Talks into a more institutionalized structure due to the regional specifics. However, in a region lacking any institutions, any hope for regular multilateral negotiations is great progress. Differences in interests of the particular states taking part in the negotiations and only one common goal is not enough to create minimal the confidence that is needed to move the Six-Party Talks to the next level of institutionalization. The reason for cooperation in the Northeast based on the Six-Party Talks is negative - other states want to contain North Korea from developing missile and nuclear programs, but they do not see the Talks as a ground for solving security problems not directly connected with Pyongyang policy. In addition, it is highly impossible to imagine including issues other than security, understood in the traditional Cold War way, into negotiations between these six states. Some scholars argued that even though after the end of the Cold War and especially after the Asian Financial Crises of 1997 there was a will to establish an international organization of Asian states or some less formal institution. The circumstances were used by the Association of Southeast Asian Nations (ASEAN) to deepen cooperation between them and to create new forms of cooperation with states that are not members of ASEAN. A number of different initiatives created by ASEAN, such as ASEAN+ and the Regional Forum, seem to be another solution to Northeast Asia's lack of a suitable platform for cooperation, as all countries from this region, except for North Korea, are taking part in the East Asia Summit (B. Carr, 2012). The ASEAN activity towards North East Asian states makes is not less likely to expand the Six-Party Talks' scope to positive reasons for cooperation due to the fact that all of those initiatives were created for economic reasons. Thus, they are better equipped to deal with cooperation in spheres other than security.

Although it may take time the idea of the Six-Party Talks will have a continuation, maybe with modifications. In the current circumstances there does not exist a better solution for the Korean Peninsula problem. In the case of a difficult situation, even imperfect but prepared resolutions are better than establishing some temporary structure anew. The specifics of the region and North Korea's regime suggests that in the near future the Six-Party Talks' framework might be needed, for it will be easier to use it than to seek new arrangements.

\section{Conclusion}

The Six Party Talks are limited in nature, because of the goals that their creators wanted to achieve when they established them. What is more important, the states are not really interested in changing this situation. In Northeast Asia the lack of 
regional organizations and institutions is a result of a long-lasting division created in the $19^{\text {th }}$ and the $20^{\text {th }}$ centuries. Northeast Asia is still a region of highly conflicting interests between the states, not only between great powers, and the unbalanced relationship between those is the main problem. Strong, collective memories of past conflicts are an obstacle to creating a transnational social movement that might be helpful in improving relations on a social level. Paradoxically the need to deal with common threats, such as North Korea's missile and nuclear programs, is probably the only way to establish any form of cooperation in the region in the near future. However, as long as states are not willing to include other conflicting issues into multinational negotiations, there is no hope for a quality change. It is difficult to imagine a transformation in the existing forms of dialogue and cooperation in the traditional international organization, but there is hope that those solutions will help to provide security and stability in the region, which is necessary for its further development.

\section{References}

“Anti-Japan protests erupt in China over islands row". (2012). Reuters. URL: <http://www.reuters. com/article/2012/09/15/us-china-japan-idUSBRE88E01I20120915> [accessed September 18, 2012].

Baisong Jin. (2012). "Diaoyu row lands Japan's economy in hot water", Global Times, URL: $<\mathrm{http} / / /$ www.globaltimes.cn/content/733916.shtml $>$ [accessed September 18, 2012].

Calder Kent and Ye Min. (2004). "Regionalism and Critical Junctures: Explaining the 'Organization Gap' in Northeast Asia", Journal of East Asian Studies: 191-226

Calder Kent and Ye Min (2010). The Making of Northeast Asia, Stanford, California: Stanford University Press.

Carr Bob. (2012). "The East Asia Summit: Building our Regional Architecture for the 21st Century", Australian Minister for Foreign Affairs. URL: <http://www.foreignminister.gov.au/articles/2012/bc_ar_120706.html>[accessed September 18, 2012]

Duss Peter. (2008). „The Greater East Asian Co-Prosperity Sphere Dream and Reality”, Journal of Northeast Asian History: 143-154

Gause Ken. (2012). "Leadership Transition in North Korea", Council on Foreign Relations. URL: $<$ http://www.cfr.org/north-korea/leadership-transition-north-korea/p27071> [accessed September 18, 2012].

Gross domestic product 2009, World Bank. URL: <http://siteresources.worldbank.org/DATASTATISTICS/Resources/GDP.pdf $>$ [accessed September 10, 2012].

Haliżak Edward. (2004). Regionalny kompleks bezpieczeństwa Azji Pótnocno-Wschodniej, Warszawa: Wydawnictwo Naukowe SCHOLAR.

Haliżak Edward. (2006). Wspólnota Pacyfiku a Wspólnota Wschodnioazjatycka, Warszawa, Wydawnictwo Naukowe SCHOLAR.

Immanuel Wallerstein. (2010). "Northeast Asia in the Multipolar World-System", Asian Perspective: 191.

Katzenstein Peter J. (1997). Introduction: Asian Integration in Comparative Perspective, in Network Power: Japan and Asia, ed. Peter J. Katzenstien and Takashi Shiraishi, Ithaca and London: Cornell University Press. 
Keohane Robert O. (1989). International Institutions and State Power: Essays in International Relations Theory, Boulder, Colorado: Westview Press.

Kim Samuel S. (2004). "Regionalization and Regionalism in East Asia", Journal of East Asian Studies: $39-67$

Kuisong Yang. (2010). „The Sino-Soviet Border Clash of 1969: From Zhenbao Island to SinoAmerican Rapprochement", Cold War History: 21-52.

Kukułka Józef. (2007). Historia współczesna stosunków międzynarodowych 1945-2000 z kalendarium 2001-2006, Warszawa: Wydawnictwo Naukowe SCHOLAR.

Larin Victor. (2006). Chinese in the Russian Far East: Regional views, in Tsuneo Akaha, Anna Vassilieva ed., Crossing National Borders: International Migration Issues in Northeast Asia, Tokyo: United Nations University Press: 47-67.

Lee Jean H. (2012). "North Korea Rocket 2012: Launch Reported by South Korea”, The Huffington Post, April 12, 2012. URL: <http://www.huffingtonpost.com/2012/04/12/north-korea-rocket2012-1_n_1422319.html> [accessed September 18, 2012].

Lukin Alexander. (2003). The Bear Watches the Dragon. Russia's Perception of China and the Evolution of Russian - Chinese Relations Since the Eighteen Century, (New York: M. E. Sharpe, Inc.,)

Lüthi Lorenz M. (2008). The Sino-Soviet Split: Cold War in the Communist World, (Princeton University Press,)

"New Leadership in China". The New York Times. November 13, 2012. URL: <http://www.nytimes. com/2012/11/14/opinion/will-chinas-new-leaders-offer-real-change.html?_r $=0>$ [accessed September 18, 2012]

Nye Joseph. (1968). International Regionalism, Boston: Little, Brown and Company.

Otsuka Taku. (2011). "Prospects of Multilateralism in Northeast Asia", Pacific Forum CSIS, Issues and Insights: 63-68.

Park John S. (2005). "Inside Multilateralism: The Six-Party Talks", The Washington Quarterly: 75-91.

Robinson Thomas W. (1972). "The Sino-Soviet Border Dispute: Background, Development and the March 1969 Clashes", The American Political Science Review: 1175-1202.

Snyder Scott. (2008). "Prospects for a Northeast Asia Security Framework", paper prepared for conference "Towards a Northeast Asian Security Community: Implications for Korea's Growth and Economic Development", Washington D.C.

Snyder Scott and Byun See-Won. (2011). "Cheonan and Yeonpyeong: The Northeast Asia Response to North Korea's Provocations", Royal United Service Institute Journal : 74-81.

Suzuki Shogo. (2004). "China's Perceptions of International Society in the Nineteenth Century: Learning More About Power Politics?", Asian Perspective: 115-144.

Timmermann Martina 2008, Institutionalizing Northeast Asia: Challenges and opportunities, in Institutionalizing Northeast Asia: Regional steps towards global governance, ed. Martina Timmermann and Jitsuo Tsuchiyama, (United Nations University Press,), 1-18

Van Ness Peter. (2008). "Designing a Mechanism for Multilateral Security Cooperation in Northeast Asia”, Asian Perspective: 107-126.

Watt Louise. (2012). "Taiwanese ships have water fight over disputed islands". URL: <http://www. mercurynews.com/nation-world/ci_21627049/japanese-taiwanese-ships-have-water-fightover-disputed $>$ [accessed September 25 2012].

Zhao Tingyang. (2006). "Rethinking Empire from a Chinese Concept ‘All-under-Heaven' (Tianxia)", Social Identities: 29-41. 